\title{
Emergence of Secular Travel in Bengali Cultural Universe: Some Passing Thoughts
}

\author{
Simonti Sen \\ Professor of History \& Director in the Directorate of State Archives, West Bengal. \\ Email: sensimonti@gmail.com
}

\begin{abstract}
This paper by no means presumes to provide a comprehensive analysis of the genesis and ramifications of Bengali travel consciousness either in thematic or chronological terms. It only seeks to highlight certain key aspects of Bengali 'secular travel' culture as it germinated in the colonial period. The term Bengali specifically implies the world of Hindu bhadralok and bhadramahila from where emerged the earliest writers of 'secular' travel accounts. This is of particular interest because travel, apart from pilgrimage, had no sanction within the traditional Brahamanical orthodoxy. The same cannot be said of the Islamic paedia, which was favourably inclined towards travel. Yet in the colonial period Bengali Muslims did not, in general, produce travel narratives of the 'secular modern' variety. One outstanding exception will be considered in this article. Travel among Bengalis took different forms. While there grew a tradition of travel within the country and producing books on them from the early eighteenth century, books on journeys to Europe and different eastern countries received the attention of publishers towards the end of nineteenth and early twentieth century. All these narratives are replete with binaries, such as we/they, home/ world and similar other usual tropes of articulation of 'Self' and the 'Other'. The essay will end with a brief discussion of Deshe Bideshe (account of Kabul from 1927 to early 1929) by Syed Mujtaba Ali, which was quite exceptional in terms of both content and mode of 'telling'.
\end{abstract}

Keywords: secular travel, Bengali society, colonial period, binaries of vision, Hindu bhadralok

Mahabishwey, maha kashey, maha kalo majhe ami manaba ekaki bhrami bishwayey...

[In the vast Universe, in vast skies, timelessly; $\mathrm{Me}$, a lone mortal roam in wonder... ]

--Rabindranath Tagore, Gitanjali

\section{Features of secular travel}

One can hardly expect that such an expression invested with a sense of 'I' pitted against the 'timeless' universe could come from a pre-modern Bengali poet. Such an utterance is quintessentially linked to the arrival of 'modernity' in Bengali life. The term 'modernity' here is used in the commonly used sense implying the moment when the Bengali/ Indian literati had their lives and beliefs transformed in many diverse ways by the spirit of European Enlightenment reaching them under the aegis of the colonial rule. It is widely known by now that of the various modular forms derived from the West that went into the shaping of 'modern' Bengali/Indian social praxis, 'travel' was a major one. Several books and articles have been written on this perspective. To avoid repetition I will, therefore, only highlight a few essential features of the secular travel culture that

(C) AesthetixMS 2020. This Open Access article is published under a Creative Commons Attribution Non-Commercial 4.0 International License (http://creativecommons.org/licenses/by-nc/4.o/), which permits non-commercial re-use, distribution, and reproduction in any medium, provided the original work is properly cited. For citation use the DOI. For commercial re-use, please contact editor@rupkatha.com. 
developed among Bengali intelligentsia as part of a new ethic and aesthetic of socio-political existence.

By the end of the nineteenth century, travel, for colonized Bengali intelligentsia, did not merely symbolize personal enterprise; it had emerged as a communitarian imperative. However this identity between private and community enterprise was not confined to the project of travel alone, many of the contemporary enterprises testify to an indistinguishable continuum between 'self and 'community', an idea explored by Dipesh Chakraborty (1992), in "Postcoloniality and the Artifice of History: Who Speaks for 'Indian past?" The Western paradigmatic division of private and public was never so neatly applicable to Bengali consciousness and sometimes it still is not. Compared to the enormous amount of travel literature produced in the West right from the so-called Classical period, the ancient as well as medieval literature of Bengali Hindus is curiously marked by the absence of the traveller or travel story. Brahmanical orthodoxy, heavily biased in favour of sedentary existence, was not only disinclined towards travel or bhraman, in fact, it clearly discouraged it. It was only in case of pilgrimage that travelling was not only allowed but was considered the supreme-most act of achieving holiness. The notion of travel as an autonomous cultural practice emerged only under the influence of a new world view. This phenomenon also coincided with the production of a host of travel literature of various genres by Hindu Bengali literati discussed in details in my book Travels to Europe: Self and Other in Bengali Travel Narratives 1870-1910 (2005).

It is worthy of note that a similar phenomenon did not emerge among the Bengali Muslims, although travelling was never discouraged or prohibited within the Islamic worldview. In fact, medieval safarnamas (travel accounts of Indo-Persian or Indo-Arabic tradition) constitute a substantial body of literature. Yet barring a few exceptions we barely get from the Bengali Muslims elites of the contemporary period (from the late $19^{\text {th }}$ till the middle of the $20^{\text {th }}$ century) secular travel accounts akin to the Bengali Hindu variant. The analysis of why it was so demands a separate essay.

\section{Call of the new land}

The ideas of stability and certainty of home were seriously destabilized under the impact of colonial rule. While this was largely the result of existential compulsions under the new political regime, influence of Western literature also played a very significant role. On one hand, it kindled the imagination of the new literati with a notion of Romance, and on the other, it awakened in them a spirit of nationalism and patriotism. To know one's land and people was the first and primary step for acquiring the knowledge of 'self and finding a basis for the imagination of a composite nation. The act of travelling was further boosted by the innovations in modes of communication. The Western educated colonized elite suddenly discovered a route to 'freedom' - it was not only a freedom from the precincts of home; it was a freedom of consciousness from the trappings of tradition and barriers of custom to seek the fulfillment of the 'modern self'.

About the influence of the Romantics on the Bengali vision of social and natural order, Nirad. C. Chaudhuri, the famous Bengali scholar-litterateur, provided a provocative and sweeping theory. In his book Bangali Jibone Romoni he wrote, “...when the idea of Romantic love flowered in Bengali mind, it completely blended with the love of nature's beauty of Bengal, appreciation of nature's beauty being as novel an idea as that of romantic love."(1965, p. 78). According to Chaudhuri, both the appreciations-of nature's beauty and romantic love-were Western derivatives. It was through their avid exploration of the world of Byron, Shelley, Keats and their ilk 
that the new Bengali had learnt to express fascination for nature's 'bewildering beauty'. In Jiban Smriti (1959, first published 1912) Tagore wrote,

At the end of Chaitra we set off for Dalhousie hills....The call of the Himalayas had made me restless. While riding the jhampan on the way up, we could see that every tilt and fold of valley and plain was aflame by variety of spring crops of unceasing colours. (p. 51)

This is not the language of a pilgrim looking for footprints of Shiva or Vishnu in nature; it was the language of a person endowed with modern romantic consciousness who had learnt to appreciate beauty for beauty's sake. Whether we accept the full import of Chaudhuri's analysis or not, it can be said that nationalism and romanticism blended inextricably to promote travel as a cultural as well as a political project. The connection between imbibed Romanticism and travel in the genesis of Bengali travel culture has also been explored by Inderpal Grewal (1996).

This essay attempts to present an overview of different genres of travel writing that emerged in Bengal from the latter half of the nineteenth century to roughly the mid-twentieth century by looking into a selective specimen of accounts.

\section{I: Travel within the country and the formation of identity}

Before going to the accounts that had a clearer purpose of bringing to the readers a picture of the 'nation' in its diversity of beliefs and social mores, I will briefly deal with the continuing tradition of Himalaya Bhraman (Travel to the Himalayas).

Like Rabindranath Tagore and his father Debendranath, many others had strongly felt the 'call of the Himalayas' and its 'peaceful environs'. In his famous travelogue Manimahesh, Umaprasad Mukhopadhyaya, the lawyer and an exceptional travel enthusiast, recounting his many travels in the Himalayas and its forests which he had been undertaking from late 1920s wrote,

...especially travelling in forests is a great learning experience. (There are) so many places and so many new people to know. Strangers they were, yet appeared like close relations, as if known from time immemorial. Besides every road there was as if a home of my own. From the forest officials to general workers-not in their city offices, but in the loneliness of forests-everyone appeared like close relatives. (Mukhopadhaya, 1987, p.5)

One cannot miss the echo of the celebrated romantic craving for a rural/natural idyll as an escape from urban squalor and bustle.

In the first half of the twentieth century great many Himalayan travel accounts saw the light of publication. Although they often read like earlier accounts of pilgrimage, the imprint of the changing times is unmistakable. Apart from using modern aids like camera (emulating European photographic representation of Indian mountains) to elicit authenticity, these accounts, replete with references to mundane niceties of travel organization, interactions with people and citations from British travel accounts, in a way 'de-sacralised' the 'sacred spaces' and acquired a feel and texture of modern travelogues. In his article "The Himalayan Travels of the Bengalis" (2010), Rabin Pal gives us detailed information about this genre of travel narratives.

\section{Nation comes to life}

Travel accounts of the country produced by Bengalis were both in English and vernacular, and were of various forms -plain narrative, diurnal recording, epistolary and even imaginary accounts. Focusing majorly on The Travels of a Hindoo, Volume 1 by Bholanauth Chunder, I will just touch 
upon a few others to delineate certain common themes and generic specifics. The travel accounts of these days clearly reflect the historic mission mentioned at the outset. As Sengupta and Basu inform us, (1998, pp. 384-85) Bholanauth Chunder (1822-1910) studied in Hindoo College along with luminaries namely Michael Madhusudan Dutt, Bhudeb Mukherjee and others, all of whom had eaten from what Partha Chatterjee (1997) defines as 'Macaulay's poison tree'. Introducing The Travels of a Hindoo (published as a monograph in 1869 after being serialized in the Saturday Evening Englishman) Bholanauth wrote, "But unhappily we have not to relate here the adventures of Ulysses or Sindbad. Ours is a lowly tale of matter-of-fact, drawn from the scenes of every-day life and from sights of everybody's familiarity."(1869, p.2) Bholanauth was not only aware of the grand tradition he was operating within; he also clearly spelt out the difference in his purpose.

Moving from Calcutta to Delhi (1845), following the course of Ganges and Jamuna up to Delhi, Bholanauth's travel was akin to the Grand Tours, once prevalent in the West. Deeply appreciative of the rulers' benevolence in bringing 'education' to the natives, he dedicated his account to Sir John Laird M. Lawrence, Viceroy and Governor-General of India. Before reaching Delhi along the course of Ganges and Jamuna, he moved along various places such as Baranagar, Serampore, Chandernagore, Triveni, Nuddea, Cutwa, Murshidabad, Patna, Benaras etc. In the portrayal of these places, legends, myths and their location in the literary tradition of Mangal Kavyas (pre-modern Bengali tales ostensibly for religious purpose) were almost equally balanced by narrations of their recent histories related to European settlements. Last but not the least, came the positivistic enumeration of the current settlers in terms of their behavioral-sartorial habits, professional inclinations, religious faiths and so forth. Strewn all over are effusive appreciations of nature's beauty. For instance:

Beautiful passage! The banks of Hooghly, for miles, present the most gay picturesque scenery. On either hand are gardens and orchards decked in an eternal verdure, and the eyes revel upon landscapes of richest luxuriance. (Chunder, 1869, p.18)

Just as Chaitanya, the Vaishnava movement and its associated reforms claimed a very large share of the narration of these places, so did the Battle of Plassey. For all this, the author relied as much on the local histories in circulation as much on British evidence. For instance, in his description of the Santhals, the eyes and observations of English ethnographers served as his own. He began by referring to Colonel Wilford's observations (p.11) (as expressed in his Comparative Essay on the Ancient Geography of India) about their history and racial specifics as found in Rig Vedic and Puranic references. Finally as a native ethnologist himself, Bholanauth presented the much celebrated Santhal/tribal archetype:

Naked, and snake-eating, and unlettered as he is, the Santhal, too, has a code of honour and morality. He is distinguished for nothing so much as his truthfulness. The civilized man hates lying, but the pure-minded and straightforward Santhal knows not lying. (Chunder, 1869, p. 116)

Deep reverence for western civilization and frequent citations of Western authority notwithstanding, Bholanauth's account is not entirely devoid of the spirit of self assertion. For instance, about Benaras he wrote, "It is the oldest post-deluvian city on globe. Ninevah, Babylon, and others had been its contemporaries. But they are all in desolation, while Benaras is still in its glory." (p.143) Bholanauth Chunder's Travels of a Hindoo in a way set the tone of travel accounts of this period. But the fact that he was writing in English with such frequent allusions to histories of the Classical age and later European history indicates that he was not so much writing for the Indian readers as he was writing for the consumption and appreciation of the rulers. Yet his effort was one of the earliest examples as to how the Bengali literati was assuming a voice of its own by 
expressing its intellectual accoutrements and trying to forge connection with the rest of the 'nation'.

If we look at other travel accounts by Bengalis during the latter half of the nineteenth and early twentieth century and beyond, we come across certain common features. Just like the travel accounts of the mountains, many of these travel narratives were also embellished with photographs of two kinds-ancient monuments and day to day life of local people. Dharanikanta Lahiri Chaudhuri's Barat Bhraman, (Calcutta, 1910), Surendranath Roy's Uttar Paschim Bhraman, (Calcutta, 1907) are a few examples. The photographs not only served to highlight the authenticity of the authorial 'seeing', they were also means to enlighten their Indian readers with a mode of imaging of their own. The authors of these accounts, like Bholanauth, displayed their familiarity with European visioning of India, but tried to rescue their own voice by re-exploring their culture in terms existing myths, legends, and histories.

This project of forging a national identity was also a project of marking pan-Indian middleclass distinctiveness, the seeds of which could be found in Bholanauth's travelogue as well. In Baradakanta Sengupta's Bharat Bhraman (Calcutta, 1877), in Nabin Chandra Sen's Prabasher Patre (Calcutta, 1915) or in Fakir Chand Chattopadhyaya's Pather Katha (Calcutta, 1911) the theme of dress recurred constantly. They said in one voice that the literati all over India preferred Western attire. Despite a grain of uneasiness in such observation, they clearly expressed their ease in their interactions with these people of similar social background. The inevitable counterpart of identifying the same class of people was to differentiate between other classes and create a hierarchy in terms of everything-from sartorial habits to use of dialect and caste norms.

In almost every discussion occurred the theme of Muslim rule. Here we come across a kind of ambivalence among the Hindu Bengali authors. While praising the Mughal architectural and other achievements, they none the less held Islamic rule responsible for the degradation of Hindu society, especially in so far as the status of Hindu women was concerned.

Beyond caste, class and religion, another crucial aspect of identity formation centered round their discussion of Indian women. Nabin Chandra Sen even added a separate chapter to his account-'Picture of Indian Women.' From the meticulous care with which these writers described the dress, manners, educational achievements of women of different provinces, it becomes evident that they were trying to convey to his readers that if the geographic identity of a place is marked by the specifics of its nature and its historical identity by its monuments, the core of the society is most crucially exemplified by its women. Thus it was in the travel narratives that we find the seeds of the larger nationalist discourse based on a triadic identity between, nation, home and women. This analysis is found in detail in Kumkum Chatterjee's article "Discovering India: Travel, History and Identity in Late Nineteenth and Early Twentieth-century India” (1999).

In those days, travel was essentially a male project; barring one or two exceptions, women participated primarily as companions. If travel was a male project, travel writing was doubly so. Very few women recorded their 'seeing' and those who did generally replicated the pattern and theme of the extant travelogues by men. That is to say, the patriarchal discursive parameters determined women's vision as well as expression. That said, it hardly escapes notice that in their ways of representation, in their stresses and inflections, we do find traces of women's own voice that denied submergence in the larger sound track.

As far as travel within the country was concerned, this essay will confine itself to a very brief discussion of the travel account by Prasannamoyee Devi. Aryavarta: Janaika Bangamahilar Bhraman Brittanta (1888) was the first published travel account of India by a Bengali woman. 
Prasannamoyee, having suffered a failed marriage at the age of ten, received quite unconventional education at home and became a prolific writer. ${ }^{1}$ Her travel account Aryavarta (northern part of the Indian subcontinent marked as the homeland of the ancient Aryans), the result of a long travel in Northern and Western India undertaken with the specific purpose of health recovery, is a testimony of the learning she acquired as a pupil of English, Bengali and Sanskrit tutors. Prasannamoyee began by providing an apology for her act of recording her experiences:

But the way things appear in the eyes of men may not appear the same in the eyes of a woman. Thus with my limited knowledge I have dared to write mainly for the benefit of those who might be curious to know as to how the various places of the Aryavarta wrapped in history appealed to the eyes and heart of a woman from Bengal. (1888, p.51)

Another expressed purpose of her writing was to enlighten her daughter of the great Hindu glory of the past, how it declined and became a slave of handful of foreigners(p.52) - a purpose that lends an over didactic tone to her account. From her elaborate account, this essay will only refer to a few snippets of her observation.

Women's education recurred as an important theme. She felt that the 'Hindustani's were yet to realize the importance of women's education as it has been realized in Bengal' (p. 57) However, she was not really impressed by the behaviour of Bengalis residing in upper India. They appeared a bit too much self indulgent for her taste. (p. 59) Although fascinated by the Taj Mahal, she nonetheless made an approving reference to an article by an Englishman in The Statesman where the writer observed that instead of spending so much money to build a mausoleum in the memory of her beloved wife, Shahjahan would have done better to have utilized the money for public welfare.(p.63) The splendour of Mughal architecture filled her with despair by the thought that all good times were ephemeral. Flow of time sees to the decline of even the greatest.(p.84) But for all her ruminations over the golden days of the Mughals and their great achievements, she could not trust the Muslim 'orderly' appointed to their service at the hotel despite not ever finding him at fault.(p.85)

\section{II: Travel Abroad}

\section{Travelling West}

Travelling within the country was not enough to know the 'Self', travelling abroad and getting a taste of alien culture was equally important to know one's strengths and foibles. After the Suez Canal was opened in 1869 , travel to Europe was rendered easier. It was also the time we begin to see publication of books on travels to Europe. Much before they had gone to Europe, the Bengal intelligentsia already knew the land owing to their close familiarity with European literature. From the mist of England or the organization of urban life, from the advancement of women or middle class liberalism to the misfortune of the working classes in a fast industrializing society -nothing was unknown to them. Thus in Ramesh Chandra Dutt's description of the condition of the working class squalid living, one could actually reread Dickens or get an idea of Italian natural beauty from his quotes from Byron's Childe Harold's Pilgrimage. While Europe was largely appreciated through European lenses, we often come across slippages when the narrators, conscious of their subject position, would try to find their own voice and own lens to view things. Thus we come across mismatches between 'what I had read' or 'what I had heard' and 'what I see now' along with indications of areas where India/Bengal won. The two main themes that entailed prolonged discussions of the comparative estimate of Hindu versus European social organization were related to the status of women and the issue of poverty. On the first issue while the travellers, of course not 
without reservation, concurred about greater freedom and advancement of women in Europe, on the issue of poverty and charity they more or less tended to endorse the superiority of Hindu swabhab (nature) and samajik byabahar (social behaviour). I discuss these issues in greater details in my book Travels to Europe: Self and Other in Bengali Travel Narratives 1870-1910.

Compared to the travelogues by men, Bengali women's travelogues of the West, for reasons quite obvious, are few and far between. Between 1870 and 1940 two full-length travel accounts of Europe were by Krishnabhabini Das (Englande Bangamahila, 1885) and Durgabati Ghose (Paschim Jatriki 1936). In nutshell it can be said, Durgabati recording her impressions almost fifty years later than that of Krishnabhabini, from the initial days of her journey displayed a criticality about Western ways that was hardly expected of Krishnabhabini writing at a time when Bengali/Indians were yet to gain the confidence of going it alone. In most of the oppositions that Durgabati created, India appeared the stronger opponent. However, on the issue of the progress of women, a cardinal theme of most of the earlier travel accounts, Durgabati is almost silent. According to Amitranjan Basu, this perhaps is largely explained by her liberal home ambience (she was the daughter of Girindra Shekhar Bose, the famous psychoanalyst and reformer) where educating women was no longer a matter of debate. Durgabati, being a member of a more self-confident elite corps, could not possibly write like Krishnabhabini:

If anyone asks me which one of the several differences obtaining between India and England did strike me most, I answer in brief, while England is the land of freedom India is one of servility. It is said that even a slave, immediately after setting foot on the soil of England, becomes free. I myself experienced a different feeling as long as I inhaled the free air of England. (Das, 1885, p. 253)

\section{Travelling East}

From the early years of the twentieth century we see a tendency to explore the Eastern horizon. With the burgeoning of the idea of 'Greater India', nationalism had found a firmer ground under its feet. Along with Japan, China and South Asian islands, explorations of Central Asia had also begun. Apart from big names like Rabindranath Tagore (e.g, Japan Yatri 1918, Java Yatrir Patra 1929), Indumadhav Mallik (Chin Bhraman, 1911) and Benoy Kumar Sarkar (Chiner Bauddha O Confusian Dharma, Chinader Jiban Yatra, Chiner Dunia Pujo, Pekinger Nana Mahallay etc., all published in Prabasi, 1916) and so on, the East was also explored by women like Hariprabha Takeda and Sarojnalini Dutt. In all these accounts variety of tropes were employed to bring home to the readers an image of India's 'glorious past' when she was the civilizer, a role unfortunately usurped by the Europeans in the present times.

However, it will be simplistic to try to read into every travel account by Bengalis of the time some kind of social or political purpose; people also responded to the call of the unknown and had personal dreams to fulfill. Thus Bimal Mukherjee, undeterred by all uncertainties and risks, set out on a world tour on a bicycle. His account of the tour from 1926 to 1937 was later published in a book form as Du Chakay Dunia (1986).

\section{From Travel to Travel industry}

Generally 'Grand Tours' are considered to be the beginning of travel industry in the West. These were undertaken mainly by the aristocrats who monopolized the administrative posts. These tours, it was believed, would add to their ability to better discharge their responsibilities. Significantly Francis Bacon had placed the essay 'Of Travel' in between two other essays namely 'Of Superstition' and 'Of Empire' in his book, The Essays, or Counsels, Civil \& Moral (1625). 
The main destinations of English Grand Tours were generally central Italy and Rome. Sometimes they extended till Switzerland and the Austrian Alps. From the eighteenth century onwards it was noticed that apart from aristocrats, the middle classes had started participating in these tours. But it was after the 'take off' of the industrial revolution in the mid-eighteenth century and the accompanied revolution in the system of communication that travel industry got the real boost. But it was actually the growth of capitalist economy and incessant workers' movements demanding reduction in work hours and work days that compelled the capitalists to develop tourism as leisure industry to control and regulate the leisure time of the workers. Gradually, as Jozef Borocz (1992) mentions, the countries of Europe came to be categorized in terms of heritage, natural beauty, progress and development, and so on.

To return to Bengal, the basic areas of travel had been introduced by the British rulers. Hill stations, sea-side locales, forests etc. acquired a special significance as 'sites for sights.' Beyond those mentioned above, from the 1870 on onwards, after Bengal and places of Bihar got connected through railways, there began a perceptible trend among middle class Bengalis to go to these places and set up temporary habitations. These were long-term leisurely tours when the Bengali baboos would interact with the local tribal populace deriving all sorts of economic and extra-economic advantages from them. ${ }^{2}$ However, with the spread of global capitalism the travel history started following more or less the same trajectory in both East and West. From the 1970s this relaxed culture of travel started drying up and 'packaged tours' organized by tour operators became the diction of the day.

\section{A different tune}

Not every travel account subscribed to the standard mode of writing through its usual tropes of 'othering' and maintaining a clear separation between the 'Home' and the 'World'. Syed Mujtaba Ali's journey to Afghanistan during this period presents an example of one such exception. One of the greatest litterateurs, humorists and also an astounding linguist, Syed Mujtaba Ali, having graduated from Visva-Bharati was summoned by Prof. Benoit and Prof. Bogdanov, both his teachers in Santiniketan, to join the Department of Education in Kabul to teach English and German. Responding to their bidding Mujtaba Ali started for Kabul in 1927 and arrived there via Peshawar. His sojourn in Afghanistan, then in the throes of intense tribal feuds and Anglo Russian competition for gaining influence over this region, lasted for roughly a year and a half till the middle of 1929. Deshe-Bideshe, a record his experience there, after being serialized in the magazine Desh, was published in book form in 1949 owing to its popularity. This was essentially a reminiscence reconstructed after almost a lapse of twenty years.

The first part of his narrative consisted of an account of his travel across the sub-continent through Khyber Pass with a variety of people steeped in their own worlds of beliefs. The humour with which Mujtaba presented the cultural confusions of this first part of journey through Desh, like the rest of the account transforms his enterprise into what Tapodhir Bhattacharya calls a 'carnival of hilarity.' (2005, p. 49) Wit blended so perfectly with the meditative and lengthy digressions into history and politics that readers barely feel that his journey could have any other end apart from revelling in marvels hidden in people and in moving on with them. Mujtaba was a passionate and involved traveller who, while away from home, found home everywhere. His 'seeing' instead of locating differences or discovering 'others' discovered parts of his 'self' in every mores

and manners, in every interaction or in idioms and turn of phrases that he set out to describe about this 'home away from home'. 
During his short stay in Peshawar he was awestruck by the hospitality of the Pathans. He got a taste of it right at the station through his encounter with Sheikh Ahmad Ali, the person who had come to receive him:

He somewhat snatched me from the train and almost carried me out to get seated in a carriage. I wondered as to why a Pathan would be so eager to welcome a Bengali. Was this mere formality or a real sincere gesture? ...Today I can say that every bit of Pathan hospitality is sincere and real. (Ali, 1949, p.25)

The Pathans not only stood out for their hospitality, they were hankers for companionship and were absolutely democratic about this. An aristocrat could indulge in tittle-tattle with an ordinary cobbler for hours on end. (Ali, pp.36-37) The same applied to Pathans having meal together. The food was much less important than sitting together and gossiping to no end.

Reaching Kabul though an extremely arduous journey he met, among others, Adbur Rahaman, his personal servant, a character immortalized by his pen. Throughout the period of his eventful teaching assignment, Abdur Rahaman remained his loyal informant and savior through all the trials and tribulations that he had to undergo in Kabul. Apart from his constant interaction with French, German, Russian and English embassy officials, he befriended several leading Afghan personalities so much so that he started getting invitations for their household ceremonies. But for all his close encounters with Afghan life, a brewing political disturbance remained a hindrance to his closer exploration of the society. In his inimitable style and scholarship Mujtaba narrated in detail the historical trajectory of Afghan politics, especially the present in which he willy nilly became a participant. (Ali, pp.119-129) The histories of India and Afghanistan had such overlaps and similarity that he felt it was a mere prejudice to treat their histories in isolation of each other. (Ali, pp. 126-27)

The author's sojourn in Kabul coincided with King Amanullah's reign. The new king having secured the throne through a series of intrigues organized at the Afghan court, tried to modernize the country along Western lines while declaring war with the English. Amanullah's rash and unpremeditated methods of reform made him immensely unpopular and invited backlash from tribal chief Bacha-e-Saqao and led to the outbreak of the Sinwari revolt. Life in Kabul became turbulent and unsafe, exacerbated by a freezing cold winter. People had to go without food and the author was taken terribly ill and managed to survive primarily owing to Abdur Rahaman's tender care and protection. Finally owing to a much- delayed dispensation of the English embassy, the author was able to board the plane for India. The depiction of Abdur Rahaman's grief during the author's departure can be placed on the list of time-honoured classical tragedies. (Ali, pp. 392-394)

Although Mujtaba Ali preferred to see Deshe Bideshe as a travel account, it is not a travel account in the usual sense of the genre. Like most of his other writings it is also of a mixed character that does not follow the limits of any generic boundary. The account moves in the mood of free chatting or majlishi adda which according to Tapodhir Bhattacharya does not have a fixed telos.(2005, p. 39) It is in part rumination, in part exchange-free-flowing all the while. The triadic structural neatness of the standard travel accounts -- from home to the other world and finally back to the origin-- does not bind the account. The author takes a great deal of warmth which he recognizes as part of his own ethos from Afghan soil and leaves a lot of his 'self' to the gossipy, laid back, rebelling and caring Afghans.

While it is difficult to find an account of travel and residence in an 'alien' clime as fascinating as Deshe Bideshe, Bengali travel narratives in general, even beneath their patterned 
response, displayed outstanding diversity in both content and style. The above discussion has dealt with only a slender slice of the magnificent corpus.

\section{Notes}

${ }^{1}$ Devi Prasannamoyee, Purba katha 1982, Calcutta, Reprinted from 1917 by Subarnarekha, mentioned in Murmu Maroona, Prasannamayee Devi: Imagining and Imaging Aryavarta, Journal of History, vol.27, 2009-10

${ }^{2}$ How the Bengali baboos spent days in regions like Santhal Parganas was a staple theme of Bengali literature (It perhaps begins with Palamau by Sanjib Chandra Chattopadhyaya) and cinema (e.g., Aranyer Dinrati by Satyajit Ray based on the eponymous novel by Sunil Ganguly) for a long time.

\section{References}

Ali, S.M.(1949). Deshe Bideshe. Calcutta: New Age Publishers Ltd.

Basu, A. (2007). Introduction. Paschim Jatriki by Durgabati Ghose. Kolkata: Dey's Publishing and School of Women's Studies.

Bhattacharya, T. (2005). Deshe Bideshe: Mujtabar Bhabnabishwa. Deepan, Nos. 1 \& 2. Sept 2004-March 2005, pp. 39-49.

Borocz, J. (1992). Travel-Capitalism: The Structure of Europe and the Advent of the Tourist. Comparative Studies in Society and History Vol. 34, No. 4, pp. 708-741.

Chatterjee, Kumkum. (1999). Discovering India: Travel, History and Identity in Late Nineteenth and Early Twentieth-century India, in Daud Ali (ed). Invoking the Past: Uses of History of South Asia New Delhi: Oxford University Press.

Chatterjee, Partha. ( 1997). Macaulay's Poison Tree. Present Politics of West Bengal: Essays in Political Criticism. New Delhi: Oxford University Press.

Chakrabarty, D. ( 1992). Postcoloniality and the Artifice of History: Who Speaks of Indian Past. Representations 37, pp. 1-26

Chaudhuri, N. C. ( 1965). Bangali Jibane Ramani. Calcutta: Mitra O Ghosh.

Chunder, B. (1869). The Travels of a Hindoo to various parts of Bengal and Upper India. (2 volumes). London: N.Trubner \& Co. http: archive.org/details/travels

Das, Krishnabhabini. (1885). Englandey Bangamahila. Calcutta: Banerjee Press.

Devi, P. (1888). Aryavarta. Calcutta: Sri Kalidas Chakraborty.

Devi, P. (1917). Purba katha. Calcutta. Rpt. (1982) Kolkata: Subarnarekha.

Dutt, S. (1928) Japane Banganari. Rpt. (2010) Simonti Sen (ed.), Indumadhaber Chin Bhraman. Sarojnalinir Japane Banganari, Kolkata: Chhatim Books.

Ghose, D. (1936). Paschim Jatriki. Calcutta: Ranjan Publishing House. Rpt. (2007). Kolkata: Dey's Publishing and School of Women's Studies.

Grewal, I. (1996). Home and Harem: Nation, Gender, Empire, and the Cultures of Travel. Durham and London: Duke University Press.

Mandal, S. (ed). (2010). Indian Travel Narratives. Jaipur \& Delhi: Rawat Publications.

Mandal, S. (ed). (2013). Journeys: Indian Travel Writing. New Delhi: Creative Books.

Mukherjee, B. (1986). Du Chakay Dunia. Calcutta: Swarnakshar Publications. 
Mukhopadhyay, B. (2002). Writing Home, Writing Travel: The Poetics and Politics of Dwelling in Modernity. Comparative Study of Society and History, April 2002, pp.293-318.

Mukhopadhyaya, U. (1987). Manimashesh. Bhraman Omnibus 2 Kolkata: Mitra O Ghosh.

Murmu, M. (2010). Prasannamayee Devi: Imagining and Imaging Aryavarta. Journal of History, vol.27, 200910.

Nandy, A. (2010) Foreword. The Westward Traveller by Durgabati Ghose. Tr. Somdatta Mandal. New Delhi: Orient Blackswan.

Pal, R. (2010). The Himalayan Travels of the Bengalis in Mandal, Somdatta, Ed. Indian Travel Narratives. Jaipur \& Delhi: Rawat Publications.

Sen, N.C. (1915). Prabesher Patre. Calcutta: 1915

Sen, S.(2005). Travels to Europe: Self and Other in Bengali Travel Narratives 1870-1910. Hyderabad: Orient Blackswan.

Sengupta, S. C. and Basu, A.(eds) (1998). Sansad Bangali Charitabidhan, vol..1. Kolkata: Sahitya Sansad.

Tagore. R. (1912).Himalaya Yatra. Jiban Smriti. Rpt 1959, Kolkata: Viswa Bharati Granthalaya.

Takeda, H. (1915). Bangomahilar Japan Yatra, Dhaka: Kumari Santiprobha Mullick; Rpt. (1999) Dhaka: Sahitya Prakash.

\section{Bio-note}

Simonti Sen, Professor of History in West Bengal Education Service, has served in many colleges in West Bengal. She is currently posted as the Director in the Directorate of State Archives, West Bengal. Working on Bengali travelogues and gender issues for a long time, she has several related articles in both English and Bengali. Her major works include: Krishnabhabini Daser Englandey Bangamahila, Ed with annotation (Calcutta: Stree, 1996); Travels To Europe: Self and Other in Bengali Travel Narratives, 1870-1910 (Hyderabad: Orient Blackswan, 2006); Indumadhaber Chin Bhraman and Sarojnanilir Japane Banganari, Ed. with annotation (Kolkata: Chhatim Books, 2010); They Dared: Essays in Honour of Pritilata Waddeder. Ed. (Kolkata, Gangchil, 2011). 